\title{
PRAYER AND ALTRUISTIC DESIRE AS PREDICTORS OF HAPPINESS
}

\author{
Michael Babula \\ Assistant Professor of Psychology \\ Khalifa University of Science and Technology, Abu Dhabi (UAE)
}

\begin{abstract}
Suldo and Shaffer (2008) identify a dual factor model of mental health with well-being and mental illness at opposite ends of the spectrum. The objective of positive psychology is to investigate ways to make people happier. This is a difficult task given the international rise of mental illness. The study undertaken here reports on a comparative analysis of results from wave six (2010-2014) of the World Values Survey (WVS) for the USA $(n=2,232)$, Thailand $(n=1,200)$, India $(n=4,078)$, and Turkey $(n=1,605)$ to examine the positive mental health benefits of prayer versus using religion for altruistic purposes. These countries were selected for analysis in attempt to explore general differences based on representations of the world's major religions as well as the underlying effects of individualism and collectivism on happiness. The USA's concept of the pursuit of happiness is very much rooted in individualism. Although the USA has separation of church and state, the sample contains participants from across the religious spectrum. The other countries under investigation are considered collectivist and have religious majorities that identify with Buddhism in Thailand, Hinduism in India, and Islam in Turkey. Logistic regression analysis confirmed that prayer is significantly associated with increased happiness in India and Turkey. In India, those who pray often were more likely to report being happy than participants who do not pray (adjusted odds ratio $(\mathrm{AOR})=2.14,95 \%$ confidence interval $[\mathrm{CI}]=1.47,3.12)$. In Turkey, those who pray often were also more likely to report being happier than participants who do not pray (adjusted odds ratio $(\mathrm{AOR})=2.43,95 \%$ confidence interval $[\mathrm{CI}]=1.33,4.42)$. Prayer was not significantly associated with happiness in the United States or Thailand. Surprisingly, logistic regression analysis for using religion as a means 'to do good to other people' versus 'to follow religious norms' only significantly predicted happiness in India. Self-reports of prayer appear to be better predicting happiness in collectivist countries such as India and Turkey. Implications about focusing on the welfare of others are discussed.
\end{abstract}

Keywords: Mental health, happiness, social connections, prayer, altruism.

\section{Introduction}

People throughout history have turned to religious activities in seeking happiness. Two emerging themes in the literature is that prayer and altruism may predict happiness. The O'Connor et al. (2012) study reported that people who were other-focused as opposed to self-focused during meditation had lower depressive symptoms, maladaptive guilt, anxiety, and empathetic distress. Fredrickson et al. (2008) conducted a research study on the effects of loving-kindness meditation (LKM) on depression and overall life satisfaction. Fredrickson et al. paraphrases Salzberg (1995) to define LKM as "a technique to show feelings of warmth and caring for the self and others" (p. 3). The findings showed that LKM produced greater positive emotions which predicted greater life satisfaction and lower depressive symptoms. Post (2005) cited Luks (1988) to observe that, "Two thirds of helpers report a distinct physical sensation associated with helping; about half report that they experienced a "high" feeling, whereas $43 \%$ felt stronger and more energetic, $28 \%$ felt warm, $22 \%$ felt calmer and less depressed, $21 \%$ experienced greater self-worth, and 13\% experienced fewer aches and pains" (p. 71).

The primary research that follows investigates whether prayer versus the desire for altruistic action predict greater levels of happiness. The results of a comparative study on four countries below offer insight that prayer is significantly associated with happiness in India and Turkey whereas the desire for altruistic action only shows significance in predicting happiness in India. 


\section{Method}

A comparative analysis of data from wave six (2010-2014) of the World Values Survey (WVS) for the USA $(n=2,232)$, Thailand $(n=1,200)$, India $(n=4,078)$, and Turkey $(n=1,605)$ was used to examine the prayer versus using religion for altruistic purposes as a predictor for happiness. These countries were selected for analysis in attempt to explore possible differences based on representations of the world's major religions. Although the USA has separation of church and state, the USA sample contains participants from across the religious spectrum. The other countries under investigation have religious majorities that identify with Buddhism in Thailand, Hinduism in India, and Islam in Turkey. The WVS has two question items that are of interest in exploring this phenomenon. The question items used for analysis asked, "Apart from weddings and funerals, how often do you pray?" and "Taking all things together, would you say you are: Happy/Rather happy/Not very happy/Not at all happy." An additional item in the analysis asked, "With which one of the following statements do you agree most. The basic meaning of religion is to: Follow religious norms and ceremonies/To do good to other people." The variables for prayer and happiness were transformed into bivariate dummy outcome and predictor variables to facilitate logistic regression analysis.

\section{Results}

Table 1 shows the results of prayer in predicting happiness in the four countries under investigation. The data reveal that prayer significantly predicts greater happiness in India and Turkey. In India, the desire to use religion to do good for others significantly predicted happiness albeit the odds ratio was rather weak (adjusted odds ratio $(\mathrm{AOR})=.76,95 \%$ confidence interval $[\mathrm{CI}]=.59, .98$ ). The use of religion to do good to others did not significantly predict happiness for the other countries under investigation.

Table 1. Logistic regression predicting happiness from prayer.

\begin{tabular}{lcccc}
\hline $\begin{array}{l}\text { Apart from weddings } \\
\text { and funerals, how often } \\
\text { do you pray? }\end{array}$ & $\begin{array}{c}\text { Participants } \\
\text { reporting that are } \\
\text { happy, No (\%) }\end{array}$ & $\begin{array}{c}\text { Participants reporting } \\
\text { that they are not } \\
\text { happy, No (\%) }\end{array}$ & Sig $^{\mathrm{a}}$ & exp b $^{\mathrm{b}}(95 \%$ CI $)$ \\
\hline India & $2450(70.1)$ & $306(62.4)$ & .000 & $2.14(1.47,3.12)$ \\
Thailand & $414(37.8)$ & $20(24.7)$ & .672 & $1.38(.310,6.16)$ \\
Turkey & $1096(82.9)$ & $183(73.8)$ & .004 & $2.43(1.33,4.42)$ \\
United States & $1311(66.5)$ & $137(63.7)$ & .126 & $1.32(.925,1.90)$
\end{tabular}

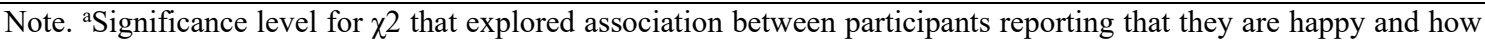
often they pray. ${ }^{\mathrm{b}}$ The predicted change in the odds ratio, $\mathrm{CI}=$ confidence interval (rounded up to two decimal places).

\section{Discussion}

The finding that stands out the most is that prayer in India and Turkey predicted greater levels of happiness. One assumption is that the sense of collectivism and importance shown towards others in these countries effects levels of happiness. In other words, people in collectivist cultures who value strong social bonds are more inclined to pray for others such as their family or members of the community rather than for the self, increasing well-being and positive emotions. Suchday et al. (2018) conducted a survey on young people in Mumbai and found "Identification with being Indian correlated with collectivism $(\mathrm{r}=.23)$, religiosity $(\mathrm{r}=.29)$, spirituality/wellness $(\mathrm{r}=.16)$, and karma $(\mathrm{r}=.23)$ indicating strong association between self-perceived Indianness and traditional values" (p. 146). Yorulmaz (2016) also conducted a research study in Turkey using WVS data and found the same connection between prayer and happiness, but that research did not comment on causality. Yorulmaz's logistic regression models would suggest that religiosity served to increase happiness somewhat independently of income although hierarchical analysis was not used to explore for interactions between the predictor variables. Yorulmaz cited Okulicz-Kozaryn (2010) who suggested that it is not the religion that makes people happy, but rather, the social setting it offers. 
Collectivism provides some insight as to why prayer in India and Turkey predicted happiness compared with the USA which values individualism. However, Thailand is a collectivist culture where the majority of the population believes in Buddhism. And yet, Thailand offers a conundrum in that prayer did not significantly predict happiness. Balthip et al. (2017) cited the Ramajitti Institute (2012) to indicate that while more Thai youth pray, there has been a shift away from the belief ".... in the law of Karma that influences the consequences of one's deeds" (p. 296). Balthip et al. also cites Call et al. (2012) to state that, "Urbanization, globalization, and technology are impacting the family structure and the quality of connection among family members, which has diminished the traditional upbringing by an extended family" (p. 296). These observations stand in stark contrast to the strengthening of collectivist culture witnessed in India. Thus, the untethering of collectivism in Thailand might be one reason why prayer is not a predictor of happiness although there is not enough data at present to show causality.

\section{Areas for future research}

There is an important finding in this study that the desire to use religion to do good for others only predicted happiness in India. The results are surprising as one would intuitively think that an altruistic attitude would have a much greater impact than prayer as a predictor of happiness. To reiterate, Post (2005) and Luks (1988) highlighted an association between altruism and positive mental health benefits. The LaPiere (1934) study may offer some insight as to why the desire to do good did not predict happiness in Turkey, Thailand, and the USA. That research study indicated that attitudes do not always reflect actual behavior. As a result, the self-reports to use religion to do good do not necessarily translate into actual altruistic action and increased happiness. To reiterate, the Suchday et al. (2018) research indicated that Indian youth still significantly identify with the concepts of karma, collectivist values, and spirituality/wellness. Such values for Indian youth might contribute to altruistic attitudes being put into action although the odds ratio in predicting happiness was weak. Future research is advised to conduct naturalistic observation and experiments to observe whether religious individuals engaged in actual altruism and volunteerism predict happiness.

\section{Acknowledgement}

The author disclosed receipt of the following financial support for the conference paper: This work was supported by Khalifa University’s Faculty Start-Up funds [project number: FSU 2019-06].

\section{References}

Balthip, K., Mcsherry, W., Petchruschatachart, U., Piriyakoontorn, S., \& Liamputtong, P. (2017). Enhancing life purpose amongst Thai adolescents. Journal of Moral Education, 46(3), 295-307. doi: 10.1080/03057240.2017.1347089

Call, K. T., Riedel, A. A., Hein, K., Mcloyd, V., Petersen, A., \& Kipke, M. (2002). Adolescent Health and Well-Being in the Twenty-First Century: A Global Perspective. Journal of Research on Adolescence, 12(1), 69-98. doi: 10.1111/1532-7795.00025

Fredrickson, B. L., Cohn, M. A., Coffey, K. A., Pek, J., \& Finkel, S. M. (2008). Open hearts build lives: Positive emotions, induced through loving-kindness meditation, build consequential personal resources. Journal of Personality and Social Psychology, 95(5), 1045-1062. doi: $10.1037 / \mathrm{a} 0013262$

Inglehart, R., C. Haerpfer, A. Moreno, C. Welzel, K. Kizilova, J. Diez-Medrano, M. Lagos, P. Norris, E. Ponarin \& B. Puranen et al. (eds.). 2014. World Values Survey: All Rounds - Country-Pooled Datafile Version. Madrid: JD Systems Institute. Retrieved from http://www.worldvaluessurvey.org/WVSDocumentationWVL.jsp

Kashdan, T. B., \& Roberts, J. E. (2004). Social Anxietys Impact on Affect, Curiosity, and Social Self-Efficacy During a High Self-Focus Social Threat Situation. Cognitive Therapy and Research, 28(1), 119-141. doi: 10.1023/b:cotr.0000016934.20981.68

LaPiere, R. T. (1934). Attitudes vs. Actions. Social Forces, 13(2), 230-237. doi: 10.2307/2570339

Luks, A. (1988). Helpers high. Psychology Today, 22(10), 39.

O’Connor, L. E., Berry, J. W., Stiver, D. J., \& Rangan, R. K. (2012). Depression, Guilt, and Tibetan Buddhism. Psychology, 03(09), 805-809. doi: 10.4236/psych.2012.329122 
Okulicz-Kozaryn, A. (2010). Religiosity and life satisfaction across nations. Mental Health, Religion \& Culture, 13(2), 155-169. doi: 10.1080/13674670903273801

Post, S. G. (2005). Altruism, happiness, and health: it's good to be good. International Journal of Behavioral Medicine, 12(2), 66-77. doi: 10.1207/s15327558ijbm1202_4

Ramajitti Institute. (2012). Child watch during 2011-2012. Retrieved June 2, 2017, from https://www.teenpath.net/data/r-research/00011/tpfile/00001.pdf

Salzberg, S. (1995). Loving kindness: the revolutionary art of happiness. London: Shambhala.

Suchday, S., Santoro, A. F., Ramanayake, N., Lewin, H., \& Almeida, M. (2018). Religion, spirituality, globalization reflected in life beliefs among urban Asian Indian youth. Psychology of Religion and Spirituality, 10(2), 146-156. doi: 10.1037/rel0000161

Suldo, S. M., \& Shaffer, E. J. (2008). Looking beyond psychopathology: The dual-factor model of mental health in youth. School Psychology Review, 37(1), 52-68.

Yorulmaz, Ö. (2016). Türkiyede Dindarlık ve Mutluluk Arasındaki İlişki: Dindar İnsanlar daha mı Mutlu? Cankiri Karatekin Universitesi Iktisadi Ve Idari Bilimler Fakultesi Dergisi, 6(2016-2), 1-1. doi: 10.18074/cnuiibf.430 